\title{
Aikuisopetuksen kehittäminen on myös oppimateriaalin kehittämistä
}

Pantzar, Eero. 1981. Aikuisopetuksen kehittäminen on myös oppimateriaalin kehittämistä. Aikuiskasvatus 1,2, 60-63. Artikkelissa tarkastellaan aikuisopetuksen oppimateriaalin asemaa didaktisissa teorioissa ja käytännössä. Erityiskohteena artikkelissa on kirjallinen oppimateriaali. Esiin tulevat aikuisopetuksessa tarvittava oppimateriaali, sille asetetut erityisvaatimukset ja tutkimustulosten valossa analyysi nyt käytössä olevista ja käyttöön suositelluista kielten oppikirjoista aikuisille.

Artikkelissa päädytään havaintoon kirjallisen oppimateriaalin jonkinasteisesta jälkeenjääneisyydestä. Tilanteen korjaaminen voi tapahtua kehittämällä Aikuiskoulutuskomitean kaavailemaa oppimateriaalituotannon organisaatiota, joka antaisi mahdollisuuden toiminnan laajentamisen omatekoisen ja kaupallisen oppimateriaalituotannon ulkopuolelle.

Aikuisdidaktisia teorioita tarkasteltaessa havaitaan opetuksen suunnittelun malleissa otettavan huomioon myös oppimateriaali. Puhutaan oppimateriaalin analyysistä, valinnasta jne. (esim. Peltonen 1981, 190-195; Grahm \& Mellander 1974, 95-96; Sauvala 1978, 109-110; Beiträge 1973, 93-94).

Oppimateriaali voidaan määritellä materiaaliksi, joka välittää opiskelijoille ne tiedot, taidot ja asenteet, jotka suunnittelussa on koulutuksen tavoitteeksi asetettu (Oppimateriaalikomitea, 2). Operationaalisesti määriteltynä oppimateriaali sisältää kirjallisen materiaalin ${ }^{1}$, audiovisuaalisen materiaalin sekä oppimispelit ja niihin rinnastettavan materiaalin (Lehtinen \& Stenström 1975, 2).

Teoriassa, mallien tasolla kaikki näyttää olevan kohdallaan. Kuinka on käytännössä? Jääkö oppimateriaali kaikkinensa siihen laatikkoon, jossa se sinänsä hyvässä ja käyttökelpoisessa mallissa on. Käytännön aikuisopetuksessa näyttää usein todellakin siltä, että oppimateriaali, sen suunnittelu ja kehittäminen eivät ole kovin merkityksellisiä asioita. Usein tärkeistä, onnistuneen aikuisopetuksen monista edellytyksistä juuri oppimateriaaliin kohdistuvat toimenpiteet joutuvat karsinnan kohteeksi, yleensä kustannustekijöihin vedoten. Tosin on aiheellista pohtia, olisiko myös aikuisopetuksen didaktiikkaan liittyvä tiedonpuute vähäisen kiinnostuksen takana.

1 Kirjallinen materiaali sisältää oppi- ja kurssikirjat, työkirjat, harjoituskirjat, oheislukemistot ja opettajien ohjekirjat.
Tässä artikkelissa tarkastellaan erityisesti aikuisopetuksen kirjallista oppimateriaalia ${ }^{1}$, sen erityispiirteitä, tarvetta, nykytilaa sekä eräitä tutkimustuloksia nyt käytössä olevista ja käyttöön soveltuvista materiaaleista. Vaikka kasvatuksen alueella kirjallista materiaalia, erityisesti oppikirjaa, ei aina pidetä parhaimpana mahdollisena oppimateriaalina, näyttää aikuisopetuksen osalta asiaa arvioitavan toisin. Kirjallisen materiaalin on katsottu aikuisopetuksessa olevan hyvinkin keskeisessä asemassa (Huuhka 1974, 2).

\section{Hyvä oppimateriaali ja aikuisopetuksen erityisvaatimukset}

Hyvä oppimateriaali on tietenkin suhteellinen käsite eikä näin ollen ole olemassa mitään ehdotonta määritelmää. Eri käsityksistä voidaan laatia seuraava luettelo yleisistä hyvän oppimateriaalin ominaisuuksista:

- oppiaines ilmentää pätevyyttään nykyaikaisuutena ja ajan tasalla olemisena

- oppiaines ymmärrettävyydellään ja havainnollisuudellaan täyttää tehokkaan viestinnän kriteerit

- oppiaines etenee ja on jaksoteltu oppimista edistävän opetussuunnitelman mukaan

- oppimateriaali on käyttökelpoinen aktivoija muille tiedonlähteille ja opintojen jälkeisenä lähteenä

- oppimateriaali on kohtuuhintaista (Alanen 1974, 10-11; Lehtinen \& Stenström 1975, 9). 
Yleiset hyvän oppimateriaalin ominaisuudet pätevät luonnollisesti myös aikuisopetuksessa käytettävään kirjalliseen materiaaliin. Toisaalta aikuiskasvatukseen liittyy tekijöitä, jotka asettavat erityisvaatimuksia oppimateriaalille. Alanen mainitsee tällaisina tekijöinä

- aikuiskasvatuksen tavoitteiden voimakkaan eriytyneisyyden,

- aikuisopiskelijan toimimisen työelämässä,

- tietojen ja suoritusvaatimusten nopean muuttumisen,

- tarpeen mahdollisuuteen edetä yksilöllisin tavoittein ja omaa tahtia,

- aikuisopiskelijoille yleensä tyypillisen itsenäisyyden ja pitkäjännitteisyyden,

- aikuisen kyvyn tuottavaan ryhmätyöskentelyyn ja

- tarpeen mahdollisuuteen kerrata ja tarkistaa oppimaansa (Alanen 1974, 11-15).

Kouluhallituksen perusasteen aikuisopetussuunnitelmassa vuodelta 1976 kiinnitetään huomio siihen, että opiskelijat ovat aikuisia, joilla on erilaiset oppimisvalmiudet, erilainen kokemustausta ja erilainen opiskelumotivaatio. Nämä piirteet opetussuunnitelman mukaan on otettava huomioon oppimateriaalia valittaessa. (Kouluhallitus 1976, 3)

Voidaankin sanoa, että aikuisopetusta varten on oltava käytettävissä sellaista oppimateriaalia, joka:

- palvelee suhteellisen pienien ryhmien tarpeita

- on sisällöllisesti joustavaa uudistettavaksi tietojen ja suoritusvaatimusten muuttuessa

- on aikuista opiskelijaa motivoivaa ja akttivoivaa

- soveltuu erilaisiin aikuisopetuksen organisointimuotoihin

- sisällöllisesti ottaa huomioon opiskelijain aikuisuudesta johtuvat tekijät. (vrt. Alanen 1974, 11-15 ja Kom.miet. 1975, 129-130)

Tarkasteltaessa aikuisopetuksen kirjalliselle oppimateriaalille asettamia erityisvaatin iksia unohdetaan yksi olennaisesti asioihin vaikuttava tekijä. Tällaisena pidän sitä, että määrällisesti merkittävimmän osan opetusta antavat sivutoimiset aikuisopettajat. Tästä on seurauksena aikuispedagogisten valmiuksien puute ja nähtävästi työskentelymotivaation suuntautuneisuus toisin kuin päätoimisessa opetuksessa. Valmiin, hyvin suunnitellun materiaalin avulla voitaisiin opetuksessa korvata edellä mainituista tekijöistä johtuvia puutteita. Puuttuvan kirjallisen oppimateriaalin korvikkeeksi ei ko. tilanteessa aina sovi omatekoisen oppimateriaalin valmistaminen, jota joskus on peräänkuulutettu ratkaisuna oppimateriaaliongelmiin. (Tahvanainen, 1974, 39)

\section{Kirjallisen oppimateriaalin tarpeesta}

Jo viime vuosikymmenen puolella totesi Kosti Huuhka aikuisopetusta varten kirjoitetun varsin vähän oppikirjoja, jotka nekään kaikki eivät Huuhkan mukaan täyttäneet oppikirjalle asetettuja vaatimuksia. Edelleen hän totesi muutaman rohkean yrittäjän uskaltaneen uurastaa kokoon oppikirjan ja saaneen sen kustantajan kautta julkaistuksi. (Huuhka, 1974, 3)

Huuhkan julkituoma ajatus kuvastaa tuonaikaista tilannetta kolmessa suhteessa: Kirjallinen oppimateriaali oli määrällisesti ja laadullisesti vaatimatonta, oppikirjojen tekijät olivat rohkeita uurastajia ja kustantajien kiinnostus ei vielä tuolloin kohdistunut aikuisopetuksessa tarvittavaan oppimateriaaliin.

Tämän päivän tilannetta tarkasteltaessa havaitaan kirjallisen oppimateriaalin tarjonnan jatkuvasti lisääntyvän. Niin kaupalliset kustantajat kuin aikuisopetusinstituutioiden keskusjärjestöt ja monet muutkin tuottavat kirjallista oppimateriaalia yhtä hyvin vieraiden kielten kuin opiskelutaidon opiskeluun. (ks. esim. Oppimateriaalia 1980). Aikuispedagogiset vaatimukset täyttävää materiaalia on entistä enemmän, mutta niin on myös heikkolaatuistakin. 1970-luvulia näytti aikuiskasvatuksen keskusjärjestöjen tuottama oppimateriaali laadullisesti parhaalta (Huuhka 1974, 3). Tänään tasoa ei voi rajata kustantajan kaupallisuuden asteen mukaan, vaikkakin joskus näyttää siltä, että ns. kaupalliset kustantajat oppimateriaalin yhteydessä määrittävät aikuisopetus -käsitteen varsin omintakeisesti.

Kustantamiseen liittyvien ongelmien yhteydessä onkin syytä muistaa Aikuiskoulutuskomitean laatineen ehdotuksen oppimateriaalin tuotanto-organisaatioksi (Kom.miet. 1975, 83-85). Tarvittava järjestelmä toimii valitettavasti vain komiteamietinnön sivuilla ja kaavioissa.

Kirjallisen oppimateriaalin tuottamiseen aikuisopetusta varten meillä on jo olemassa varmasti kysynnän osalta määrälliset edellytykset. Joka tapauksessa esimerkiksi vapaan sivistystyön alueella on tilaa aikuisille laaditulle oppimateriaalille. Tällainen johtopäätös on helppo tehdä vertailemalla nykyistä oppimateriaalitilannetta, kiinnostusta eri aineiden opiskeluun (Pantzar 1973 a ja b sekä Kouluhallitus 1977) ja vuosittaisia opiskelijamääriä keskenään. Myös ammatillisen aikuiskasvatuksen puolella on tilanne samanlainen, tosin pienem- 
missä puitteissa (Tilastokeskus 1979). Jyväskylässä tehty tutkimus (Ylinentalo-Stenström 1974) osoitti ammatillisissa kurssikeskuksissa podettavan sekä määrällistä että laadullista pulaa oppikirjoista. Ilmeisesti on jossain määrin niin, että kaupalliset kustantajat ovat vaikeuksissa koulujärjestelmän muutosten aiheuttamien vaatimusten kanssa (HS 16.8.1981), mikä on omiaan rajoittamaan mahdollisuuksia paneutua aikuisopetuksen tarpeisiin.

\section{Vieraiden kielten oppimateriaalista}

Vast'ikää tehdyssä selvityksessä (Pantzar 1981) aikuisopetuksessa käytettävästä ja siihen tarkoitetusta kirjallisesta oppimateriaalista tutkittiin muun muassa vieraiden kielten (tässä tapauksessa englanti, saksa ja ruotsi) oppikirjojen aikuisopetukseen soveltuvuutta.

Tutkimusaineistoina käytettiin asiantuntijaryhmien ${ }^{2}$ laatimia oppikirja-arviointeja. Analyysin perustana ovat arvioijien käsitykset. Lisäksi analyysissä pyrittiin kokoamaan tietoja arviointien perusteella kiinnittämällä huomio seuraaviin aikuisopetuksen kannalta merkittäviin seikkoihin:

- sisältö (ikäkauden ja kielenkäyttötilanteiden huomioonottaminen)

- motivaatio (virittäminen ja ylläpitäminen)

- työtavat (mahdollisuudet aikuisopetukselle tyypillisten työtapojen käyttöön).

Arvioitaessa tulosten luotettavuutta voidaan sen katsoa heikentyneen kahdestakin syystä. Ensiksikin eri ryhmät ovat arvioineet eri kielten materiaalin ja toiseksi arviointi ei kaikkien arviointikohteiden osalta kohdistu täsmälleen samoihin asioihin. Arviointiryhmän jäseniä sen sijaan voi pitää riittävän kelpoisina. Analyysin kohteena olevan kirjallisen oppimateriaalin "aikuiskasvatuksellisuutta" nostanee jonkin verran se, että arviointiryhmät olivat jo ennakkoon valinneet työnsä kohteeksi edes jossain määrin aikuisopetukseen soveltuvaa oppimateriaalia (Bauters 1978, 125). Edellä mainitut tekijät kavensivat tutkimustyön kohdealuetta, mutta tutkittujen alueiden osalta tulosten luotettavuutta voidaan pitää tyydyttävänä.

Taulukko 1. Arvioitujen oppikirjojen määrä tasosuosituksen mukaan kielittäin (lkm)

\begin{tabular}{lcccc}
\hline \multicolumn{5}{c}{ Tasosuositus } \\
\multicolumn{1}{c}{ Kieli } & I-III & IV-V & Muut & Yht. \\
\hline Englanti & 6 & 6 & 12 & 24 \\
Ruotsi & 6 & 6 & 4 & 16 \\
Saksa & 7 & 3 & 3 & 13 \\
\hline Yhteensä & 19 & 15 & 19 & 53
\end{tabular}

Selvityksessä ilmeni muun muassa se, että kolmen kielen oppimateriaaleista vain runsas $1 / 10$ oli tarkoitettu alkeisryhmässä käytettäväksi (kts. taulukko 1). Kuitenkin tutkimus

osoitti toisaalta sen, että juuri alimmille tasoille käytettäväksi suositeltu materiaali on aikuisopetukseen soveltuvuudeltaan parhainta (ks. taulukko 2)

Taulukko 2. Arvio vieraiden kielten oppikirjojen aikuisopetukseen soveltuvuudesta tasosuosituksen mukaan $(\%)$

Tasosuositus

\begin{tabular}{lcccc}
\hline \multicolumn{1}{c}{ Soveltuvuus } & I-III vuosik. & IV-V & Muut & Yht. \\
\hline $\begin{array}{l}\text { Heikko tai } \\
\text { tyydyttävä }\end{array}$ & 47 & 60 & 63 & 57 \\
$\begin{array}{l}\text { Hyvä tai } \\
\text { erinomainen }\end{array}$ & 53 & 40 & 37 & 43 \\
\hline $\begin{array}{l}\text { Yht. } \\
\mathrm{n}=53\end{array}$ & 100 & 100 & 100 & 100 \\
\hline
\end{tabular}

2 Asiantuntijaryhmiin oli KTOL valinnut aikuisten kieltenopetukseen perehtyneitä ja osallistuvia opettajia. Kuhunkin ryhmään kuului 3 henkilöä. 
Taulukko 3. Arvio eri kielten oppikirjojen aikuisopetukseen soveltuvuudesta (\%)

\begin{tabular}{lcccc}
\hline Soveltuvuus & Kielet & & & \\
\hline & Englanti & Ruotsi & Saksa & Yht. \\
\hline Heikko & 8 & 37 & 15 & 19 \\
Tyydyttävä & 42 & 25 & 46 & 38 \\
Hyvä & 29 & 25 & 31 & 28 \\
Erinomainen & 21 & 13 & 8 & 15 \\
\hline Yht. & 100 & 100 & 100 & 100 \\
n=53 & & & &
\end{tabular}

Mielenkiintoinen on tutkimustulos, jonka mukaan eri kielten oppikirjat ovat aikuisopetukseen soveltuvuudeltaan erilaisia. Heikommalta tilanne näyttää ruotsin osalta, parhaimmalta englannin kielessä (taulukko 3.)

Kokonaisuutena soveltuvuudessa aikuisopetukseen on parantamisen varaa. Yksittäisenä myönteisenä piirteenä kävi tutkimuksessa esiin se, että oppikirjoissa on varsin hyvin pystytty ottamaan huomioon käyttäjäkunnan ikäkausi — aikuisuus - ja kielenkäyttötilanteet.

Kielten oppikirjoihin liittyy usein varsin runsas oheismateriaali. Tutkimus osoitti oheismateriaalin tasoltaan varsin vaatimattomaksi. Onkin vahinko, jos aikuisopetuksen vähäiset taloudelliset resurssit joudutaan käyttämään paremmin rekvisiitaksi sopivaan, usein varsin kalliiseen kirjallisuuden oheismateriaaliin.

Tutkimustulosten perusteella voidaan esittää muun muassa kiinnitettäväksi huomiota nykyistä enemmän opettajaa opastavan materiaalin kehittämiseen. Parhaimmillaan tällainen opastava materiaali voi toimia tukena luovuudelle, jolla valmiin oppimateriaalin puutteita voidaan korvata. Tulokset viittaavat edelleen siihen, että koulutuksella voidaan antaa opettajille myös hyviä, valintoja edistäviä perusvalmiuksia. Voidaan myös väittää kielten aikuisopetukseen tarkoitetun oppimateriaalin kehittämisen edellyttävän tuottamismotivaation lisäksi perehtymistä aikuisopetuksen erityisongelmiin.

\section{Lopuksi}

Aikuiskoulutuskomitean käsitys yhteiskunnan ohjaavan ja suunnittelevan osuuden lisäämisestä sekä oppimateriaalituotannon kehittämisestä opetussuunnitelmien kehittämisen yhteydessä (Kom.miet. 1975, 83) pitää edelleen paikkansa haluttaessa kehittää aikuisopetukseen tarkoitetun oppimateriaalin tuottamista.
Yllättävää onkin se, että Aikuiskoulutuksen johtoryhmä tuskin lainkaan tuo yleissuunnitelmassaan esiin oppimateriaaliin liittyviä kysymyksiä (Yleissuunnitelma 1980). Tämän voi havaita jo aienmin aikuiskoulutuksen kehittämisen periaatepäätöksestä (VnP 7.6.1978). Mikäli aikuiskasvatustoiminta ja sen puitteet määräytyvät edellä mainituista linjoista, näyttää oppimateriaalin kehittämisen näkymät vaatimattomammilta kuin v. 1975 Aikuiskoulutuskomitean mietinnön ilmestyttyä.

Käsitykseni mukaan aikuisille tarkoituksenmukainen opetus ei voi nyt eikä vastaisuudessakaan perustua sen enempää omatekoiselle oppimateriaalille kuin puhtaasti kaupallisenkaan kustannustoiminnan varaan.

\section{Lähteet:}

Aikuiskoulutuksen kehittämisen yleissuunnitelma 1980. Aikuiskoulutuksen johtoryhmä. Helsinki. (Yleissuunnitelma).

Alanen, A. 1974. Oppimateriaali aikuisopetuksessa. Vapaan sivistystyön XIX vuosikirja. WSOY. Porvoo.

Bauters, A. 1978. Kielten oppikirja-arvostelut valmistuneet. Opistolehti 4-5.

Beiträge zur Erwachsenenqualifizierung. 1973. (Autorenkollektiv): Volk und Wissen. Berlin.

Graham, Å. \& Mellander, K. 1974. Handbok för undervisare. Kristianstad.

Huuhka, K. 1974. Oppikirjatilanteesta aikuisopetuksessa. Vapaan sivistystyön XIX vuosikirja. WSOY. Porvoo.

Helsingin Sanomat 16.8.1981 (HS).

Komiteanmietintö 1973:139. Oppimateriaalikomitean mietintö. Helsinki.

Komiteanmietintö 1975:28. Aikuiskoulutuskomitean II osamietintö. Helsinki. (Kom.miet.)

Kouluhallitus. 1977. Vapaan sivistystyön osasto. Tutkimuksia ja selvityksiä 3 . Helsinki.

Lehtinen, A-R. \& Stenström, M-L. 1975. Oppikirjojen käyttökelpoisuus opettajien arviointien mukaan ammatillisissa kurssikeskuksissa. Kasvatustieteiden tutkimuslaitos. Selosteita ja tiedotteita 48. Jyväskylä.

Oppimateriaalia 1980-81. KTOL. Orivesi 1980. 
Pantzar, E. 1973 (a). Selvitys aikuiskoulutuskomitealle kansalais- ja työväenopistojen opetuksen sisällöstä 1971-72. Tampere.

Pantzar, E. 1973 (b). Selvitys aikuiskoulutuskomitealle opintokerhojen opetuksen sisällöstä 1971-72. Tampere.

Pantzar, E. 1981. Aikuisopetuksen kirjallisen oppimateriaalin tarpeesta ja käytössä olevan soveltuvuudesta erityisesti vieraiden kielten opetuksessa. Julkaisematon. Tampere.

Peltonen, M. 1981. Aikuisdidaktiikan perusaineksia. WSOY. Juva.

Perusasteen aikuisopetussuunnitelma. 1976. Kouluhallitus. Helsinki.
Sauvala, A. 1978. Koulutussuunnittelu. Otava. Keuruu.

Tahvanainen, S. 1974. Omatekoinen opintoaineisto aikuiskasvatuksessa. Vapaan sivistystyön XIX vuosikirja. Porvoo.

Tilastokeskus. Tilastotiedotus KO 1979:11. Helsinki.

Valtioneuvoston päätös aikuiskoulutuksen suunnittelu- ja kehittämisperiaatteista 7.6.1978.

Ylinentalo, O. \& Stenström, M-L. 1974. Oppikirjatilanteen kartoitus ammattikasvatushallituksen alaisissa oppilaitoksissa. Ammatilliset kurssikeskukset. Kasvatustieteiden tutkimuslaitoksen selosteita ja tiedotteita 10. Jyväskylä. 